\title{
REVISÃO
}

\section{THE DOUBLY-LABELED WATER METHOD AND FOOD INTAKE SURVEYS: A CONFRONTATION}

\author{
O MÉTODO DA ÁGUA DUPLAMENTE MARCADA \\ E PESQUISAS DE INGESTÃO ALIMENTAR: UM CONFRONTO
}

France BELLISLE'

\begin{abstract}
Surveys of food intake in humans, following measurements of energy expenditures in free-living persons, obtained by the doubly-labeled water technique, have been severely questioned in recent years. The present article reviews studies performed in both adults and children, comparing energy intake and expenditures in the same individuals. In adults, reported intake is often insufficient to cover minimal energy needs. The typical level of "under-reporting" is about $20 \%$, and it is even higher in obese subjects. Intake data obtained from children are more valid than data from adults. Different survey methods yield differing degrees of agreement between intake and expenditure measurements using the doubly labeled water technique: frequency questionnaires tend to induce over-reporting, whereas the classical 24 hours recall is very susceptible to large under-reporting. Even obese adults can provide accurate reports of their daily food intake if properly trained and motivated. The interpretation of data obtained with the doubly labeled water method should integrate the considerable day-to-day variations observed in human food intake.
\end{abstract}

Index terms: doubly-labeled water method, food intake surveys, epidemiology, energy intake, energy expenditures.

RESUMO

Pesquisas de ingestão alimentar em seres humanos, seguindo medidas de gastos de energia, obtidas pela técnica da água duplamente marcada, têm sido amplamente questionadas nos últimos anos. Este artigo faz uma revisão de estudos realizados em adultos e crianças, comparando consumo e gastos de energia nos mesmos indivíduos. Em adultos, o consumo relatado é freqüentemente insuficiente para cobrir as necessidades mínimas de energia. O nível típico de sub notificação é de cerca de $20 \%$ e chega a percentuais maiores em indivíduos obesos. Dados de consumo obtidos de crianças são mais válidos que dados de adultos. Métodos diferentes de pesquisa produzem graus diferenciados de conformidade entre medidas de consumo e gasto usando a técnica da água duplamente marcada: questionários de freqüência tendem a induzir super estimados, enquanto o clássico recordatório de 24 horas é muito suscetível a grandes sub notificação. Até mesmo adultos obesos podem fornecer relatos precisos de seus consumos alimentares diários se apropriadamente treinados e motivados. A interpretação dos dados obtidos com o método da água duplamente marcada deveria integrar as consideráveis variações do dia-a-dia observadas na ingestão alimentar dos seres humanos.

Unitermos: método da água duplamente marcada, pesquisas de ingestão alimentar, epidemiologia, consumo de energia, gastos de energia.

(1) INSERM U341, Hotel-Dieu - 1, Place du Parvis Notre-Dame - 75181 Paris, France. E-mail: bellisle@imaginet.fr 


\section{INTRODUCTION}

The body energy balance is considered one of the essential parameters of homeostatic functions. Several physiological (hunger, satiety, glycemic control, etc.) and behavioral (food choice, learning, habits, etc.) mechanisms adjust, or should adjust, energy intake (through food intake) to energy expenditures (metabolic needs, diet-induced thermogenesis and muscular activity). The energy balance must be zero so as to maintain a stable body weight. If the energy balance is negative, if intake is lower than expenditures, then the organism must extract energy from its reserves (essentially from the fat body mass) so as to cover its needs; the fat body mass decreases under those conditions and the person loses weight. If the energy balance is positive, if input exceeds output, then excess energy is deposited into the body reserves (body fat stores essentially) and the individual gains weight. This simple equation derived from the laws of thermodynamics is not questioned: the body mass is the result of the long-term integration of energy intake minus energy expenditures.

From the above, it can be deduced that there exists a minimum level of daily intake that is compatible with the maintenance of a given body mass. This level corresponds to the coverage of energy needs for basal metabolism, plus a certain fraction of the basic needs to allow for minimal movement. Until very recently, the precise level of this minimum energy intake was not objectively defined. Equations allowing for age, gender, approximate activity and body mass were used in order to assess a minimum level of expenditures. Intake should theoretically be slightly above basal metabolic expenditures; for instance, intake could be at least equal to $127 \%$ of the obligatory needs corresponding to basal metabolism (Becker et al., 1999). A modest evaluation of total energy needs is thus obtained, corresponding to a sedentary lifestyle. If physical activity is high, then intake must correspond to a higher proportion of basal metabolism.

Food intake surveys have been carried out for decades in developed countries, in this context of imprecise definition of minimal bodily needs. Several methods have been used. They have been improved with time in terms of subject selection and data processing (Galan \& Hercberg, 1999). Dietary survey methods are complex and require specific training. In most cases, specialists trained in the methods of dietary survey collect structured data, in quantitative and/or qualitative terms. Using food composition tables (for example the well-known McCance \& Widdowson Table), it is possible to assess the energy intake as well as the micro and macronutrient consumption. Intake can thus be compared in certain social strata or age groups and can be also evaluated in terms of nutritional recommendations. Intake data collected in populations are considered a valid basis for public health actions.

One often reported result of intake surveys is that obese respondents do not eat more than lean peers. This surprising observation has been reported in several developed countries, in children, in adults, in men, in women. In addition to epidemiological studies, clinical studies carried out in small groups of obese subjects report very modest daily intake, as assessed by trained dieticians. The macronutrient contents of the diet are different in obese versus non-obese subjects. Obese persons report lower intake of carbohydrates and sugar, and higher intake of proteins than controls. Dietary fat intake is sometimes lower, sometimes equal, sometimes higher in the obese than in normal weight individuals.

The doubly-labeled water method, which has been used over the last decade, has produced a plethora of data drawing a precise image of energy expenditure in free-living humans under habitual conditions. It has been used in newborn babies, children, adolescents, adults, elderly persons, in obese and normal weight individuals. The data are clear: they establish that the obese individuals have higher energy expenditures and thus higher energy needs than lean peers. Consequently, if their body weight is stable, then the obese individuals must necessarily consume an energy ration compatible with their needs. Such a high energy intake is incompatible with the modest daily consumption declared in dietary surveys. For this reason, intake surveys are now viewed with much suspicion and the problem of "under-reporting" blurs the interpretation of all epidemiological surveys.

In the present paper, the doubly-labeled water method will be described briefly. The data it has produced will be reviewed and the results from dietary surveys will be criticized on the basis of the new knowledge about energy needs in obese people. The absolute or relative character of this criticism is crucial since it determines future research, as well as the evaluation of the important efforts devoted to the assessment of food intake in humans over the last decades.

\section{THE DOUBLY-LABELED WATER METHOD}

The "doubly-labeled water" method was developed about 50 years ago (Lifson \& MacLintock, 1966), but about forty years passed before it was utilized in human nutrition research (Schoeller, 1999). It is a noninvasive, harmless technique that allows a precise measurement of energy metabolism in man. It measures total energy expenditure (basal metabolism, thermogenesis, plus exercise) over several consecutive days in a free-living person, under normal life conditions. It is thus more complete than previously used methods (metabolic room, canopy) that restrict free movement considerably. In subjects confined to a calorimetric room for several days, the doubly-labeled water method produces a measure of energy expenditure that is extremely close to that given by gas exchanges in the calorimeter (Seale et al., 1993). When the same subjects are then tested under free-living conditions using the doubly-labeled water method, their energy expenditures are higher $(+13 \%)$. 
The principle of the doubly-labeled water technique rests on indirect calorimetry; total energy expenditure is measured from the turnover rate of two stable isotopes, deuterium $\left({ }^{2} \mathrm{H}\right)$ and oxygen $18\left({ }^{18} \mathrm{O}\right)$ (Ritz \& Coward, 1995). In practice, a first urine sample is collected from the subject. Then the subject ingests a dose of doubly-labeled water $\left({ }^{2} \mathrm{H} 216 \mathrm{O}+\mathrm{H} 2{ }^{18} \mathrm{O}\right)$. The body fluid reserves and the $\mathrm{CO}^{2}$ pools are then marked. Subsequent decreases in ${ }^{2} \mathrm{H}$ reflect fluid losses, while decreases in ${ }^{18} \mathrm{O}$ signal both fluid losses and $\mathrm{CO}^{2}$ production. It then becomes possible to compute the $\mathrm{CO}^{2}$ production rate as the difference between the isotopes. Successive urine samples, one of which follows the ingestion of the oral dose and another is taken just before the end of the observation period, allow total energy expenditures to be precisely measured between samples. The method is safe for human use, even in pregnant women and newborn infants.

The dose of stable isotopes to be used is proportional to the subject's body mass. The cost of the study is then also proportional to the subject's body mass. It is thus much more expensive to test an obese adult than a newborn baby. Although the financial burden of this costly method has not discouraged experimenters, studies using the doubly-labeled water technique are always limited to small samples (a few dozen subjects at most). Therefore, the direct comparisons that can be performed between reported intake and energy expenditures in the same persons are always limited to very modest numbers of subjects.

Studies using the doubly-labeled water method are numerous, in spite of their high cost and the high level of competence requested for the production of valid data. This method is considered the "gold standard" for measuring energy needs in healthy subjects as well as in sick populations. In particular, energy needs in obese persons have been abundantly studied. The data obtained with the doubly-labeled water method have been compared to declared intakes obtained in dietary surveys. This comparison has revealed important discrepancies in obese as well as in lean individuals. Nowadays, data from doubly-labeled water studies are often used as standards for validating results obtained from dietary surveys. Doubly-labeled water data also serve as a basis for building equations that define "under-reporting" in dietary surveys (Black, 1996): when a subject declares energy intake that is insufficient to cover energy expenditures as measured by the doubly-labeled water method for subjects of the same gender, age and body size, then the subject is suspected of under-reporting his/her intake so much as to make it invalid.

\section{Energy intake and expenditures compared in the same individuals}

Numerous recent studies report both energy expenditures, as measured by the doubly-labeled water method, and declared intake, as assessed by dietary surveys, in the same subjects. Such complementary data are available in individuals of all ages, males and females, for all levels of body adiposity. Very often, although not invariably, the comparison leads to questioning the validity of the dietary survey, which indicates seemingly gross under-reporting.

\section{Studies in adults}

Most comparisons of energy intake and expenditures, confronting survey and the doubly-labeled water method, show a large degree of under-reporting of food intake. Very high levels of under-reporting are typically found in obese subjects, as well as in female athletes. In some individuals, under-reporting can be as high as $50 \%$ of energy expenditures (Schoeller, 1995).

In randomly selected subjects who participated in a survey of weighed intake or who answered the dietary history, reported intake corresponded to 82 or $81.0 \%$ of expenditures in men and women, whereas in obese respondents the values were 73 and $64.0 \%$ respectively (Black et al., 1993). In a group of 50 normal weight young adults, a 7-day dietary survey, completed by a computerized dietary history, revealed under-reporting by $20.0 \%$ or more in $48.0 \%$ of the subjects (Kortzinger et al., 1997). Healthy, normal weight women $(n=49,18-50$ year-old $)$ were first trained to evaluate and report food portions; then in a subsequent survey, they under-reported their intake by $21.4 \%$, as compared to expenditures measured by the doubly-labeled water method (Howat et al., 1994). A discrepancy of $23.0 \%$ between intake and expenditures was also reported in the general American population (Seale \& Rumpler, 1997). Low-income American women who reported their previous 24 hours intake declared a much lower energy intake $(83.0 \%)$ than expenditures (2 $197 \pm 607$ versus $2644 \pm 503$ kcalories). In the same group, the level of under-reporting was positively associated with body mass, but women with a good knowledge of reading and writing performed more efficiently (Johnson et al., 1998). A group of nine American women (48.7 \pm 5 years, $61.9 \pm 6.5 \mathrm{~kg}$ ) participated in a nutrition study; their declared food intake over seven consecutive days corresponded to $79.8 \%$ of expenditures, as measured by the doubly-labeled water method (Martin et al., 1996). In this group of subjects, the BMI and body weight showed no correlation with the amplitude of under-reporting.

Two groups of ten women (younger group $25.2 \pm 1.1$ year-old; older group $74.0 \pm 1.4$ year-old) answered a battery of dietary survey tools (weighed intake, 24 hours recall, two food choice questionnaires) (Sawaya et al., 1996). Survey results were systematically below expenditures in both groups, although some surveys methods gave better approximations than others. The authors concluded that no survey method provided valid data for the assessment of subjects' energy needs. 
In 28 subjects participating in the German study EPIC (Kroke et al., 1999) energy intake assessed by multiple survey methods (24 hrs recall, frequency questionnaires) was under-reported by $22 \%$ on the average. Only one out of the 28 subjects reported intake that was comparable with expenditures measured by the doublylabeled water method.

The SOS longitudinal study presently carried out in Sweden recruits obese patients who show a high degree of motivation for the success of their body weight loss treatment. A food intake questionnaire was developed for this population (Lindroos et al., 1999). As reported, intake was slightly, but not significantly, below expenditures. The importance of the discrepancy was not related to the BMI. This study showed that even obese respondents can report food intake in a valid fashion, when they are properly motivated.

Elderly persons (73 year-old on the average) reported food intake, using the dietary history method, which corresponded to $88 \%$ of energy expenditures (Rothenberg et al., 1998). Senior men ( $n=17 ; 72 \pm 5$ year-old) and women $(n=11 ; 67 \pm 4$ year-old) recorded their food intake over four days and filled a food questionnaire: both these methods yielded data that were significantly below energy expenditures, as measured by the doubly-labeled water method (Pannemans \& Westerterp, 1993). The same subjects were then fed the amount of energy reported in the surveys for three weeks. Their body weight decreased (minus $0.64 \pm 0.5 \mathrm{~kg}$ ). In this study, the importance of under-reporting was correlated with body mass.

Black et al. (1997) conducted studies of weighed intake in several groups of adults: women $(\mathrm{n}=18 ; 50-65$ year-old), retired men $(n=27 ; 55-87$ year-old), and ex-obese individuals after weight loss $(n=11)$. Energy expenditures were measured by the doubly-labeled water method. Three women, five men, and six ex-obese subjects reported intake that corresponded to less than $79 \%$ of expenditures.

Obese patients often report very low levels of daily food intake to their physicians (less than 1200 kcalories). Ten obese patients with very low reported intake were tested using the doubly-labeled water method over 14 days. It appeared that eight out of ten had much higher energy expenditures than declared intake, suggesting considerable under-reporting. One patient had a very low level of physical exercise with a normal basal metabolism: this person also under-reported energy intake, although to a lesser degree. Finally, one patient had very low energy expenditures, compatible with the very modest energy intake reported (Buhl et al., 1995).

The doubly-labeled water method has confirmed that obese individuals have higher energy needs and expenditures than normal weight controls. For instance, a German study has established that total energy expenditures reached $2357 \pm 504$ kcalories a day in normal weight women (BMI $20.0 \pm 1.3$ ) and $3708 \pm 367$ kcalories a day in obese peers (BMI $37.4 \pm 8.1$ ) (Platte et al., 1995).

\section{Studies in children and adolescents}

The doubly-labeled water method has established beyond doubt that energy expenditures are higher in obese children than in normal weight children (Bandini et al., 1990; Livingstone et al., 1992; Maffeis et al., 1994; DeLany et al., 1995). The high energy needs in obese children are accounted for by the large amount of metabolically active lean body mass.

Mothers or caretakers of preschool children (1.5 - 4.5 year-old) filled a four-day weighed intake diary (Davies et al., 1994). Reported intake was slightly lower (less than 40 kcalories on the average, about 10 kcalories in some children) than expenditures measured by the doubly-labeled water method.

American children aged 4-7 years reported their daily intake on three occasions over a 14 day period. The method used was the $24 \mathrm{hrs}$ recall. Over the same time period, their energy expenditures were quantified by the doubly-labeled water (Johnson et al., 1996). In this group, expenditures corresponded to intake and the dietary survey presented a reasonable assessment of energy input.

Young German subjects, aged 1-18 years, participated in a weighed intake survey in parallel with the measurement of energy expenditures with the doubly-labeled water method (Sichert-Hellert et al., 1998). Under-reporting was minimal in 1-5 year-old children (1\%), as well as in 6-13 year-old children (2-3\%), whereas it was considerably higher in adolescents (12\%) and especially in adolescent girls (20\%). The highest under-reporting was in overweight adolescent girls, who declared the lowest daily meal number, and distributed their daily intake over the shortest time over the day. These girls also reported large intakes of water, proteins, fiber, sodium, iron, niacin, zinc, but little added sugar. Under-reporting boys also consumed much water but the other effects observed in girls did not appear. Under-reporting boys stated that they usually ate more than on the day of the survey.

A seven-day food survey, without weighing intake, was carried out in 109 American girls, aged 8-12 years (Bandini et al., 1997). Reported intake reached $88.3 \%$ of expenditures measured by the doubly-labeled water method. The amplitude of the discrepancy between the two parameters increased with age and energy expenditures, but it showed no relationship with family income, ethnic origin, parents' obesity or the child's fat body mass.

Black et al. (1993) showed a high level of under-reporting in British adults but found acceptably valid reporting of weighed food intake in 7-9 year-old children, while dietary history carried out in the same children 
suggested higher intake than expenditures. In 15-18 year-old adolescents, under-reporting became apparent. A food frequency questionnaire filled by American children (White or Indian) aged 4.2 to 6.9 years, showed higher intake than expenditures measured by the doubly-labeled water technique (Kaskoun et al., 1994).

A weighed food intake survey, completed by the dietary history method, was carried out in 9 year-old Italian obese or normal weight children, while their energy expenditures were studied using the doubly-labeled water method (Maffeis et al., 1994). This study confirmed that obese children had higher energy expenditures than normal weight peers and showed significant under-reporting of intake in the obese only.

American 10-year-old children filled food diaries over 8 days, with the help of their parents. They under-reported their intake by about 17 to $33 \%$ of expenditures (Champagne et al., 1998). Under-reporting was observed in normal weight as well as in obese youths, and increased with age.

Swedish 15-year-old adolescents filled a food diary over 7 days. Declared intakes represented about $81.9 \%$ of expenditures in males, and $78.3 \%$ in females (Bratteby et al., 1998). The amount of under-reporting in this group correlated with the BMI: fatter subjects showed a larger discrepancy between reported intake and energy expenditures.

\section{Evaluation of dietary surveys on the basis of doubly- -labeled water results}

Well before the development of the doubly-labeled water method, the existence of under-reporting in dietary surveys was known. Equations computed on the basis of resting metabolism, as evaluated in a metabolic room or using a canopy, allowed a reasonable estimation of the minimum intake that could meet essential energy needs in a given subject. Every one must ingest at least as much as basal energy needs (which vary as a function of gender, age and body size) plus some extra energy to cover minimal physical movements (to stand up, sit down, speak, dress, wash, walk, etc.). If such an amount of energy is not consumed every day on average, then the body must draw energy from its reserves so as to cover these expenditures, and loses weight.

It was thus possible, even before the use of the doubly-labeled water method, to quantify the minimum intake needed to maintain the body weight of a subject, at least grossly, and to deduct from this computation that reported intake in certain individuals did not meet this minimum level. The low energy intake reported could not possibly represent habitual intake. The use of the doubly-labeled water method made possible a more precise appreciation of energy expenditures in a given person, and provided a more valid standard for comparing declared intake.
The doubly-labeled water method also confirmed what was hypothesized from body composition measurements: there is a higher obligatory energy expenditure in the obese as compared to normal weight peers. The doubly-labeled water method established that only very few obese persons who declare low energy intake also have low energy expenditures, for still unexplained reasons (Buhl et al., 1995). In the vast majority of the cases, obese subjects have resting metabolic expenditures which largely exceed their declared intake, as well as the expenditures of normal weight individuals.

Unquestionably, under-reporting creates a bias that can blur the interpretation of dietary surveys. Under-reporting could lead to under-estimation of actual intake and energy needs in a population, particularly in obese persons who under-report largely in a majority of studies. The invalidating consequences of such distortions in the data were soon recognized. Researchers carrying out nutrition surveys first tried to overcome them by simply eliminating "under-reporters" from their samples. In numerous recent studies, subjects who reported less than a certain proportion of a minimum level of expenditures were considered "under-reporters", and their data were simply eliminated before statistical treatment.

Nowadays, experts advise researchers not to simply discard the data that seemingly represent under-reporting. There are several reasons for this new strategy. First, data from a suspected "under-reporter" contain interesting information. They reveal at least a part of habitual intake. It was mentioned above that men and women who apparently under-report in terms of energy intake do show high intakes in certain nutrients, and this constitutes useful information about habitual intake (Sichert-Hellert et al., 1998). Excluding under-reporters from a survey often means discarding most information about the obese respondents in the population, and this largely decreases the survey value.

Mathematical corrections have been proposed in order to compensate for under-reporting and to maintain all respondents in the final population (Nelson, 1999). All scientific methods are imperfect, including the doubly-labeled water method and error sources exist in all scientific measurements. Nelson (1999) suggested that error sources should be identified and corrected, so that the whole body of data could be analyzed without exclusion. Algorithms have been elaborated in order to maintain the food sources as declared by the subjects, and to raise intake at a level that is compatible with the coverage of nutritional needs (Willett et al., 1997).

\section{Limitations of these criticisms}

It is important to acknowledge the fact that often, and particularly in persons with a high BMI, declared energy intake is lower than the minimal level that would allow the maintenance of the subject's body weight at the 
time of the survey. This crucial criticism, however, is relative to the exact circumstances of the measurements of intake and expenditures in the same person. A few notions about body weight changes over a time period and food intake behavior must be taken into consideration.

First, whether in obese or normal weight persons, day-to-day intake is extremely variable. Body weight is the outcome of very long-term integration (over the whole lifespan) of energy intake minus expenditures. It is not the result of the previous three or four days. Human food intake varies largely, both in quantity and quality, from day to day (Tarasuk \& Beaton, 1992). The amplitude of daily variations is an individual characteristic, but it is generally considerable. Mean coefficients of variation are about $27.2 \%$ for energy intake, and can reach up to $80.8 \%$ for vitamin C, and $102.0 \%$ for vitamin A. Record keeping must be continued for a minimum of four weeks in a single individual in order to reach a level of $10.0 \%$ in precision (Basiotis et al., 1987). In children, the same high level of variation has been confirmed in day-to-day intake (Lestrad et \& Dartois, 1992). Hypothetically, the daily variations in intake could reflect a fundamental biological mechanism allowing the child to adjust intake to variable expenditures. In consequence, it is perfectly understandable that people consume at times more, and at times less than their needs. There is nothing abnormal in the observation that a certain proportion of a surveyed population reports intake that appears lower than theoretical needs. If everyone reported higher intake than expenditures, then this would constitute an easy explanation for the rising tide of obesity in modern societies.

There are several situations where a person may very accurately and truthfully report energy intake that is lower than the average daily expenditures over a couple of weeks. When a subject, particularly an obese person, is requested to record all intakes in writing, then he or she might simplify what is actually consumed. If less is eaten, then the recording task is easier. All the more if all intake must be weighed. In addition, a person who chronically limits intake in order to lose weight might be tempted to describe a "good" day, exhibiting reasonable behavior, as much as possible. An obese person may also be on a diet during the study and his/her body weight might be slowly going down, although not significantly over the course of the examination period. In such a case, the person's declared intake might seem low in comparison with the present level of body weight but can be perfectly exact and valid. For all these reasons, it is important to avoid excluding subjects because intake does not seem to correspond to expenditures. It is crucial to establish what was actually consumed and to assess the validity of the intake report.

"Reverse causality" can also play a role in the seemingly paradoxical results obtained in dietary surveys and also in the clinician's office. It happens that being overweight alters food intake behavior: the obese person has learned certain food choices over the course of multiple periods of dieting and the dietary survey might reflect this behavior that strangely corresponds to nutrition experts' advice. This source of bias is generally overlooked. Most diets usually do not last forever and, after some time, the dieter is at risk of relapse, both in terms of food habits and body weight. Whether the survey is made on a diet or a relapse day will produce very different results. On a diet day, the subject will be diagnosed as an under-reporter, and perfectly valid declarations will be disqualified.

Let alone any bias specific to the obese persons, most survey methods actually favor under-reporting (due to forgetting, simplifying, or lying) much more than over-reporting. Main intake events, large meals, principal foods are easily remembered and reported, but it is much more difficult to accurately report snacks and side foods (condiments, bread, butter, salad dressing, etc.) (Poppitt et al., 1998 ).

The doubly-labeled water method assesses the energy expenditures of a free-living person over about two weeks. When reported intake is much lower than measured expenditures, then the person is diagnosed as an under-reporter. What about the other subjects? A subject who reports plausible intake is not necessarily a valid or exact reporter. When reported intake is equal to or higher than expenditures, there is no guarantee that it faithfully reflects what was actually consumed. Over-reporters do exist, in particular among patients with anorexia nervosa (Westerterp et al., 1992). There is a way to spot under-reporting, but over-reporting remains undetectable. It is not possible to establish whether a person who reports high intake in a survey is an over-reporter or else if this subject's activity and energy needs are indeed above average. Over-reporting probably is a lesser problem than under-reporting, but the doubly-labeled water method, which defines a minimum level of intake, does not suggest a maximum intake above which recorded intake should be suspected.

Criticism of dietary surveys, based on the doubly-labeled water method, is not always well taken. In certain conditions, surveys yield data entirely compatible with the measurement of expenditures. Survey tools are not all the same: whereas weighed intake surveys or 24 hours recall typically produce $20 \%$ of under-reported intake in numerous studies, food frequency questionnaires indicate higher levels of intake, sometimes higher than expenditures. Children declare intakes that are very close to expenditures, but accurate reporting becomes less frequent as the child grows up, especially in girls. One factor contributing to the good results obtained in children might be that an observer (parent, caretaker, etc.) does the reporting (Davies et al., 1994). The parents' participation, however, is not a sure guarantee of accuracy (Champagne et al., 1998). Reporting by an independent observer increases accuracy also in adults (Sjodin et al., 1994). Subjects who report their own intake as best as they can are much less accurate, especially if they are obese. It is possible, however, to obtain faithful reporting even in obese patients, when they are properly trained and 
motivated as the obese persons who participate in the medical program of the Swedish SOS study.

Studies using the doubly-labeled water posit that the subjects' body weight is stable over the duration of the measurement of energy expenditures. Between the moment of the initial administration of the isotopes and the last urine sample, a time period of about 10-14 days elapses. The subjects' body weight might be stable over this time, or else it might increase or decrease. The daily energy expenditures of an obese adult are approximately 3700 kcalories (Platte et al., 1995). Under-reporting by about $20 \%$ over 14 days amounts to 10360 kcalories over the period of observation. Such a difference between intake and expenditures represents $1.5 \mathrm{~kg}$ of body weight. A difference of this order of magnitude is relatively small as compared to the obese person's body weight. It is possible that, in a small $n$ study $(n<30)$, such a small change in body weight might not reach the level of statistical significance, while it is biologically significant. In addition, if the difference in body weight between the beginning and the end of a doubly-labeled water study is blurred by a number of potential confounding factors (water exchanges, ovarian cycle, ambient temperature, etc.), then the level of concordance between declared intake and measured expenditures can be underestimated.

\section{CONCLUSION}

The doubly-labeled water technique allows a precise measurement of energy expenditures in a free-living subject over a period of a few days (10-14). The method is expensive and the total cost is proportional to the subject's body mass. Its use requires a high level of technical competence. This method, for all its elegance and precision, can be used only on very limited samples. Generalizations must then be made from the data obtained on a small number of subjects in order to estimate energy needs in the general population.

Dietary surveys deal with large populations. In developed societies, a growing proportion of the population is obese. It is highly important to obtain information about the habitual food intakes in the whole population, including men and women of all ages, and all adiposity levels. It is crucial also to recognize that everyone, and especially obese individuals, tend to underestimate and under-report their own intake utilizing the most frequently used dietary survey tools. Intake data often come from obese patients who consult dieticians or physicians. In most cases, the clinical teams do not possess the technical competence or the financial means that would allow them to use the doubly-labeled water technique in order to measure the actual energy needs of their patients.

How can the costly method, limited to few laboratories and few subjects, be reconciled with the mass study method? Until now, the mass method (surveys) has been criticized on the basis of the method of choice (doubly-labeled water technique). The confrontation has been extremely useful to scientists who do dietary surveys, even though they have lost some credibility in the scientific world. The doubly-labeled water method has provided them with more precise measurements of actual energy expenditures in the humans. It therefore becomes easier to detect and correct the potential sources of error in the data. Specific methods can be used or developed in order to make dietary surveys more valid. More research is needed to confront measurements of energy expenditures over a fortnight and small amplitude changes in body weight over time in normal weight or obese subjects. The doubly-labeled water method provides a single, average value of daily energy expenditures over a few days. If this value is to be used as a "gold standard" for evaluating reported behavior, then it is crucial to take into account both the important variability of day-to-day food intake in the same person, and the small variations in body weight which may not be statistically significant over a short period study.

\section{REFERENCES}

BANDINI, L.G., SCHOELLER, D.A., CYR, H.D., et al. Validity of reported energy intake in obese and nonobese adolescents. American Journal of Clinical Nutrition, Bethesda, v.52, p.421-425, 1990.

BANDINI, L.G., CYR, H., MUST, A., DIETZ, W.H. Validity of reported energy intake in preadolescent girls. American Journal of Clinical Nutrition, Bethesda, v.65, n.4, p.1138S-1141S, 1997. Supplement 4.

BASIOTIS, P.P., WELSH, S.O., CRONIN, F.J., KELSAY, J.L., MERTZ, W. Number of days of food intake records required to estimate individual and group nutrient intakes with defined confidence. Journal of Nutrition, Bethesda, v.117, p.1638-1641, 1987.

BECKER, W., FOLEY, S., SHELLE, Y.E., GIBNEY, M. Energy under-reporting in Swedish and Irish dietary surveys: implications for food-based dietary guidelines. British Journal of Nutrition, London, v.82, p.127S-131S, 1999. Supplement 2.

BLACK, A.E., PRENTICE, A.M., GOLDBERG, G.R., JEBB, S.A., BINGHAM, S.A., LIVINGSTONE, M.B., COWARD, W.A. Measurements of total energy expenditure provide insights into the validity of dietary measurements of energy intake. Journal of the American Dietetic Association, Chicago, v.93, p.572-579, 1993.

BLACK, A.E. Physical activity levels from a meta analysis of doubly labeled water studies for validating energy intake as measured by dietary assessment. Nutrition Reviews, New York, v.56, p.170-174. 1996.

BLACK, A.E., BINGHAM, S.A., JOHANSSON, G., COWARD, W.A. Validation of dietary intakes of protein and energy against 24 hour urinary $\mathrm{N}$ and DLW energy expenditure in middle-aged women, retired men and post-obese subjects: comparisons with validation against presumed energy requirements. European Journal of Clinical Nutrition, London, v.51, p.405-413, 1997. 
BRATTEBY, L.E., SANDHAGEN, B., FAN, H., ENGHARDT, H., SAMUELSON, G. Total energy expenditure and physical activity as assessed by the doubly-labeled water method in Swedish adolescents in whom energy intake was underestimated by 7-d diet records. American Journal of Clinical Nutrition, Bethesda, v.67, p.905-911, 1998.

BUHL, K.M., GALLAGHER, D., HOY, K., MATTHEWS, D.E., HEYMSFIELD, S.B. Unexplained disturbance in body weight regulation: diagnostic outcome assessed by doubly-labeled water and body composition analyses in obese patients reporting low energy intakes. Journal of the American Dietetic Association, Chicago, v.95, p.1393-1400, 1995.

CHAMPAGNE, C.M., BAKER, N.B., DELANY, J.P., HARSHA, DW, BRAY, G.A. Assessment of energy intake underreporting by doubly-labeled water and observations on reported nutrient intakes in children. Journal of the American Dietetic Association, Chicago, v.98, p.426-433, 1998.

DAVIES, P.S., COWARD, W.A., GREGOR,Y.J., WHITE, A., MILLS, A. Total energy expenditure and energy intake in the pre-school child: a comparison. British Journal of Nutrition, London, v.72, p.13-20, 1994.

DELANY, J.P., HARSHA, D.W., KIME, J. et al. Energy expenditure in lean and obese prepubertal children. Obesity Research, v.3, p.67-72, 1995.

GALAN, P., HERCBERG, S. Mesure de la consommation alimentaire. Cahiers de Nutrition et de Diététique, Dossiers Enseignement, v.34, p.50-54, 1999.

HOWAT, P.M., MOHAN, R., CHAMPAGNE, C., MONLEZUN, C., WOZNIAK, P., BRAY G.A. Validity and reliability of reported dietary intake data. Journal of the American Dietetic Association, Chicago, v.94, p.169-173, 1994.

JOHNSON, R.K., DRISCOLL, P., GORAN, M.I. Comparison of multiple-pass 24-hour recall estimates of energy intake with total energy expenditure determined by the doubly-labeled water method in young children. Journal of the American Dietetic Association, Chicago, v.96, p.1140-1144, 1996.

JOHNSON, R.K., SOULTANAKIS, R.P., MATTHEWS, D.E. Literacy and body fatness are associated with underreporting of energy intake in US low-income women using the multiple-pass 24-hour recall: a doubly-labeled water study. Journal of the American Dietetic Association, Chicago, v.98, p.1136-1140, 1998.

KASKOUN, M.C., JOHNSON, R.K., GORAN, M.I. Comparison of energy intake by semiquantitative food-frequency questionnaire with total energy expenditure by the doubly-labeled water method in young children. American Journal of Clinical Nutrition, Bethesda, v.60, p.43-47, 1994

KORTZINGER, I., BIERWAG, A., MAST, M., MULLER, M.J. Dietary underreporting: validity of dietary measurements of energy intake using a 7-day dietary record and a diet history in nonobese subjects. Annals of Nutrition and Metabolism, Basel, v.41, p.37-44, 1997.

KROKE, A., KLIPSTEIN-GROBUSCH, K., VOSS, S., MOSENEDER, J., THIELECKE, F., NOACK, R., BOEING, H. Validation of a self-administered food-frequency questionnaire administered in the European prospective investigation into cancer and nutrition (EPIC) study: comparison of energy, protein, and macronutrient intakes estimated with the doubly-labeled water, urinary nitrogen, and repeated 24-h dietary recall methods. American Journal of Clinical Nutrition, Bethesda, v.70, p.439-447, 1999.
LESTRADE,T.H., DARTOIS, A.M. L'alimentation spontanée de I'enfant. Cahiers de Nutrition et de Diététique, v.27, p.42-49, 1992.

LIFSON, N., MACLINTOCK, R. Theory of use of turn-over of body water for measuring energy and material balance. Journal of Theoretical Biology, London, v.12, p.46-74. 1966.

LINDROOS, A.K., LISSNER, L., SJOSTROM, L. Does degree of obesity influence the validity of reported energy and protein intake? Results from the SOS dietary questionnaire. Swedish Obese Subjects. European Journal of Clinical Nutrition, London, v.53, p.375-378, 1999.

LIVINGSTONE, M.B.E., PRENTICE, A.M., COWARD, W.A. et al. Validation of estimates of energy intake by weighed dietary record and diet history in children and adolescents. American Journal of Clinical Nutrition, Bethesda, v.56, p.29-35, 1992.

MAFFEIS, C, SCHUTZ, Y., ZAFFANELLO, M., PICCOLI, R., PINELLI, $\mathrm{L}$. Elevated energy expenditure and reduced energy intake in obese prepubertal children: paradox of poor dietary reliability in obesity? Journal of Pediatrics, St. Louis, v.124, p.348-354, 1994.

MARTIN, L.J., SU, W., JONES, P.J., LOCKWOOD, G.A., et al. Comparison of energy intakes determined by food records and doubly-labeled water in women participating in a dietary intervention trial. American Journal of Clinical Nutrition, Bethesda, v.63, p.483-490, 1996.

NELSON, M. Evaluation de l'apport alimentaire en épidémiologie nutritionnelle: mise au point de méthodes de mesure cohérentes. Cahiers de Nutrition et de Diététique, v.34, p.291-299, 1999.

PANNEMANS, D.L.E., WESTERTERP, K.R. Estimation of energy intake to feed subjects at energy balance as verified with doubly-labeled water: a study in the elderly. European Journal of Clinical Nutrition, London, v.47, p.490-496, 1993.

PLATTE, P., PIRKE, K.M., WADE, S.E., TRIMBORN, P., FICHTER, M.M. Physical activity, total energy expenditure, and food intake in grossly obese and normal weight women. International Journal of Eating Disorders, v.17, p.51-57, 1995.

POPPITT, S.D., SWANN, D., BLACK, A.E., PENTICE, A.M. Assessment of selective under-reporting of food intake by both obese and non-obese women in a metabolic facility International Journal of Obesity, London, v.22, p.303-311, 1998.

RITZ, P., COWARD, W.A. Doubly labeled water measurement of total energy expenditure. Diabète et Métabolisme, v.21, p.242-251, 1995

ROTHENBERG, E., BOSAEUS, I., LERNFELT, B., LANDAHL, S., STEEN, B. Energy intake and expenditure: validation of a diet history by heart rate monitoring, activity diary and doubly-labeled water. European Journal of Clinical Nutrition, London, v.52, p.832-838, 1998.

SAWAYA, A.L., TUCKER, K., TSAY, R., WILLETT, W. et al. Evaluation of four methods for determining energy intake in young and older women: comparison with doubly-labeled water measurements of total energy expenditure. American Journal of Clinical Nutrition, Bethesda, v.63, p.491-499, 1996.

SCHOELLER, D.A. Limitations in the assessment of dietary energy intake by self-report. Metabolism, Duluth MN, v.44, p.18-22, 1995. 
SCHOELLER, D.A. Recent advances from application of doubly-labeled water to measurement of human energy expenditure. Journal of Nutrition, Bethesda, v.129, p.1765-1768, 1999.

SEALE, J.L., CONWAY, J.M., CANARY, J.J. Seven-day validation of doubly-labeled water method using indirect room calorimetry. Journal of Applied Physiology, Bethesda, v.74, p.402-409, 1993.

SEALE, J.L., RUMPLER, W.V. Comparison of energy expenditure measurements by diet records, energy intake balance, doubly-labeled water and room calorimetry. European Journal of Clinical Nutrition, London, v.51, p.856-863, 1997

SICHERT-HELLERT, W., KERSTNG, M., SCHOCH, G. Underreporting of energy intake in 1 to 18 year old German children and adolescents. Zeitschrift Ernahrungswissenschaft, Darmstadt, v.37, p.242-251, 1998.

SJODIN, A., ANDERSON, A., HOGBERG, J., WESTERTERP, K. Energy balance in cross country skiers. Medicine and
Science in Sports and Exercise, Baltimore, v.26, p.720-724, 1994.

TARASUK, V., BEATON, G.H. Day-to-day variation in energy and nutrient intake: Evidence of individuality in eating behaviour. Appetite, London, v.18, p.43-54, 1992.

WESTERTERP, K.R., VERBOEKET van de VENNE, W.P.H.G., MEIJER, G.A.L., TEN HOOR, F. Self-reported intake as a measure for energy intake, a validation against doubly-labeled water. In: AILHAUD, G., GUY-GRAND, B., LAFONTAN, M., RICQIER, D. (éd). Obesity in Europe 91. Londres : John Libbey, 1992. p.17-22.

WILLETT, W.C., HOWE, G.R., KUSHI, L.H. Adjustment for total energy intake in epidemiologic studies. American Journal of Clinical Nutrition, Bethesda, v.65, p.1220S-1228S, 1997. Supplement.

Recebido para publicação em 27 de setembro e aceito em 11 de novembro de 2000. 